第 2 表 $a$ 扩よび $n^{\prime}$ の值

樹 脂
Amberlite IRA400 $(\mathrm{RCl})$
Amberlite IRA411 $(\mathrm{RCl})$

\begin{tabular}{c|c|c|c} 
染 料 & 時間(日) & $a \times 10^{3}$ & $n^{\prime}$ \\
\hline Acid Violet & 15 & 3.2 & 0.10 \\
" & 16 & 82 & 0.19
\end{tabular}

付 記：こD研究:は保土谷化学工業株式会社研究所にお いて行なったものである。この研究にあたり, 種々ご援助をい ただいた伡藤久之博士，鈴木三男博士，および熱心に助力され た西村正栄理学士に対して扔礼申し上げる。

\title{
Studies on the Ion Exchangers
}

\author{
XIII. Ion Exchange Reaction of Anion Exchange Resins \\ with an Acidic Dye
}

\section{By Kaneyoshi Ashida}

\begin{abstract}
The rate and equilibrium of ion exchange between anion exchange resins and an acidic dye, e.g., acid violet, are investigated. Results obtained are shown as follows; (a) $\log E$ is in the linear relation with $\log P$, where $E$ is the amount of ion exchange and $P$ is the diameter of resin particle. (b) $\log E$ increases with the elapse of time, and this phenomena indicate ion exchange reaction in the resin phase. (c) The rate of ion exchange follows to the equation

$$
E=k t^{n}
$$
\end{abstract}

where $E, t, k$ and $n$ are amount of ion exchange, reaction time, and constants respectively. (d) The rate of ion exchange is influenced by the reaction temperature. (e) Amount of ion exchange of anion exchange resin with an acidic dye in alcoholic solution is very small. (f) Ion exchange equilibrium between ion exchange resin and acid violet is represented by Freundlich type of absorption isotherm.

第 14 報スルホン化フェノールとホルムアルデヒドとの酸接触重縮合 反応における脱スルホン酸基反応

(1959 年 7 月 21 日受理)

$$
\text { 芦田包義 }
$$

\footnotetext{
要 旨 スルホン化フェノール・ホルムアルデヒド樹脂の生成過程に㧍汁る脱スルホン酸基反応の諸原 因について研究を行なった。すなわち、。ーまたは p-フェノールスルホン酸, あるいはスルホン化フェノール. ホルムアルデヒド楜脂を塩酸，ホルムアルデヒドの酸性水溶液，2，6-ジメチロール 液などとそれぞれ種々の条件下反店させた。その結果, 脱スルホン酸基反応は (a) 酸接触加水分解反応と (b) メチロールカチオンおよび種々のメチレンカチオンによるカチオノイド圆換反応とによって起り，特に後者の 反応が脱スルホン酸基反㥦の主因であることを見出した。
}

\section{1. 緒言}

フェノールのスルホン化物(スルホン化フェノール; p-フェノールスルホン酸のみならず o-フェノールスル ホン酸も若干含まれている, PS と略記)とホルムアルデ ヒドとの重縮合物 (PS 樹脂と略記) の合成方法を大別す ると酸性重縮合法とアルカリ性重縮合法とに分けられ, 両法の得失を既往の文献に基いて整理すると第 1 表のご とくになる。

すなわち, 酸性重縮合法ではスルホン酸基の䧻脱が大

\begin{tabular}{|c|c|c|c|}
\hline 項 & 目 & 酸性重縮合法 & $\begin{array}{c}\text { アルカリ性 } \\
\text { 重縮合法 }\end{array}$ \\
\hline \multicolumn{2}{|c|}{ スルホン酸基の離脱 } & 大 & 小 \\
\hline \multicolumn{2}{|c|}{ 交換容量 (meq/g) } & 小 & やや大 \\
\hline \multicolumn{2}{|c|}{ 膨潤容積（cc/g） } & 小 & 大 \\
\hline \multicolumn{2}{|c|}{ 実用交換能力 $(\mathrm{meq} / \mathrm{cc})$} & 小 & 小 \\
\hline \multicolumn{2}{|c|}{ 樹脂生成速度 } & 大 & 小 \\
\hline \multicolumn{2}{|l|}{ 硬化温度 } & 低くて良い & 高温を要す \\
\hline \multicolumn{2}{|l|}{ 原料費 } & 廉価 & やや高価 \\
\hline \multicolumn{2}{|l|}{ 工 程 } & 簡單 & やや複雑 \\
\hline
\end{tabular}

第 1 表 酸性重縮合法とアルカリ性重縮合法との比較 
きいために実用交換能力 (単位容積あたりの交換容量 $\mathrm{meq} / \mathrm{cc}$ をこのように定義する)の小さい樹脂となり, こ れに対してアルカリ性重縮合法ではスルホン酸基の離脱 量はやや少ないけれども, 得られた樹脂の膨潤容皘が大 きいためにその実用交換能力はやはり小さくなってしま う。このように従来い,方法によれ酸性, アルカリ性, い ずれの方法によっても実用交換能力の小さい樹脂しか得 られていないが，第 1 表に見るように，酸性重縮合法は 工業的有利な諸条件を備えており，その上膨潤容積の小 さい樹脂が得られるという特徴があるから, 従来この方 法の致命的欠点と考えられているスルホン酸基の離脱の 多いことを改良することができれば，実用交換能力の大 きい樹脂を工業的有利に製造するここができるであろう と考えられる。そのため，まずスルホン酸基の雔脱する 原因について考察した。

\section{2. スルホン酸基の酸接触加水分解反応}

スルホン酸基が加水分解すること,およびその反応が ヒドロニウムイオンによって促進されることは知られて おり ${ }^{1)}$, その機構は (1)式のごとくであろうと考えられる。

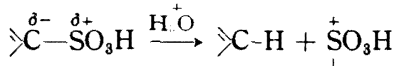

$$
\begin{aligned}
& \mathrm{HOH} \\
& \mathrm{H}_{2} \mathrm{SO}_{4}+\mathrm{H}^{+}
\end{aligned}
$$

そこでまずo-または p-フェノールスルホン酸をモデ ル物質として種々の酸濃度または温度におけるスルホン 酸基の﨎脱反応を試みて第 2〜3 表の結果を得た。スル ホン酸基の唯脱量は EDTA 試薬による硫酸根の間接定 量法"によって求めた。

第 2 表 $0.1 N \mathrm{HCl}$ 中に㧍けるつェノ一ル スルホン酸の加水分解率*

\begin{tabular}{c|c|c} 
No. & 0-スルホン酸 & p-スルホン酸 \\
\hline 1 & $7.96 \times 10^{-30}$ & $0 \%$ \\
2 & $10.6 "$ & $\prime \prime$ \\
平 域 & $9.28 "$ & $\prime \prime$
\end{tabular}

* Obermiller の方法”によって精製した。一またはn一フ エノールスルホン酸ナトリウムの $0.1 \mathrm{~mol}$ に $0.1 N \mathrm{HCl}$ を加えて全容在 $100 \mathrm{cc}$ として $100^{\circ} \mathrm{C}$ で 1 時間加熱。

第 3 表 $0.6 N \mathrm{HCl}$ 中に㧍ける $\mathrm{p}-$ フェノール スルホン酸の加水分解率*

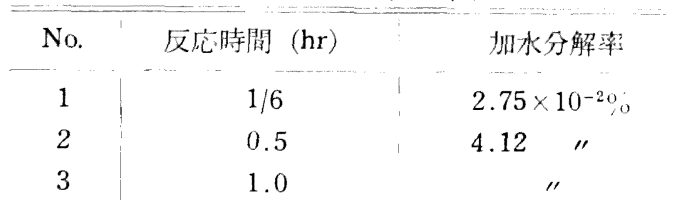

** Hoffmann の方法 ${ }^{3}$ に上って佮成した p-フェノールスル ホン酸アンモン $0.1 \mathrm{~mol} に 0.597 \mathrm{~N} \mathrm{HCl}$ 老加えて全容在 $100 \mathrm{cc}$ しして $100^{\circ} \mathrm{C}$ で加熱した。

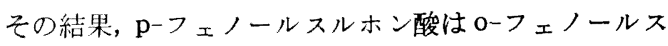
ルホン酸に比べて安定であって酸接触脱スルホン酸基反

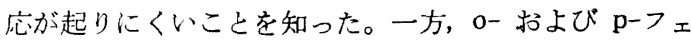
ノールスルホン酸の混合物 (PS) から合成された樹脂の 酸接触脱スルホン酸基反応は第 1 図のごとくであって,

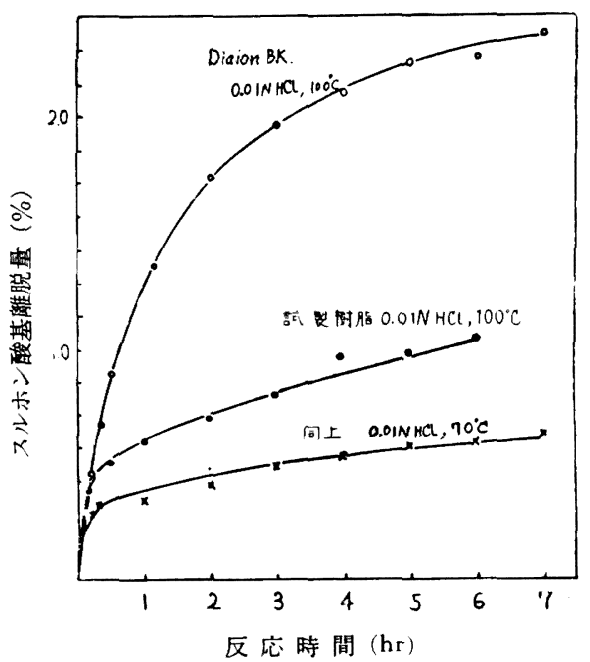

第1図スルホン化フェノールホルムアルデヒド 樹脂の酸接触加水分解反応

$0.01 N \mathrm{HCl}$ の中で 1〜 $2 \%$ のスルホン酸基の截脱が起 る。しかしながらこの僱脱量を PS 樹脂生成の際の脱ス ルホン酸基量に比べてみるときわめて小さい值であるこ とに気づくのである。すなわち，PS樹脂の棈造を

$$
\left[\mathrm{HO} \cdot \mathrm{C}_{6} \mathrm{H}_{3} \cdot\left(\mathrm{SO}_{3} \mathrm{H}\right)\left(\mathrm{CH}_{2}^{-}\right)\right]_{m}\left[\mathrm{HO} \cdot \mathrm{C}_{6} \mathrm{H}_{3} \cdot\left(\mathrm{CH}_{2}-\right)_{2}\right]_{n}
$$

(ただし $m, n$ はそれぞれ正の整数)と仮定すると 2.48 $\mathrm{meq} / \mathrm{g}_{\mathrm{HR}}$ の交換容量の樹脂はその生成過程において 70 \%のスルホン酸基が失われたことになる。

したがって, 酸の存在が PS 樹脂の生成過程における 脱スルホ之酸基反店の主原因であるとはとらてい考えら れない。ひるがえって脱スルホン酸基反応の機構を考察 すると，これは一般に(2)式に示すような力千オノイド 置換反応であると考えることができる。ただし $\mathrm{X}^{+}$は任 意のカチオンである。

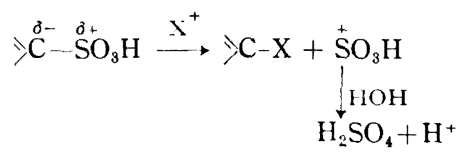

しかるに $\mathrm{X}^{+}$が $\mathrm{H}_{3}^{+} \mathrm{O}$ のよきの脱スルホン酸基反応は 前節で述べたように小さいから，PS 樹脂生成過程にお ける著しいスルホン酸基の離脱は他種のカチナンによる カチォノイド置换反応に起因していることが予想され 
る。そのため後記のような種々のカチオンとスルホン酸 基との反応を精査した。

\section{3. スルホン酸基とカルボニウムカチオンとの反応}

酸性重縮合反応によるPS 樹脂の生成過程において生 ずると考えられるカルボニウムカチオンとしては次のよ らなものがある。

$$
\mathrm{HCHO} \stackrel{\mathrm{H}_{2} \mathrm{O}}{\rightleftarrows} \mathrm{CH}_{2}(\mathrm{OH})_{2} \stackrel{\mathrm{H}^{+}}{\rightleftarrows}+\mathrm{CH}_{2} \mathrm{OH}+\mathrm{H}_{2} \mathrm{O} \text { (3) }
$$<smiles>O=C[C@H]1C[C@H](S(=O)(=O)O)CC(O)[C@H]1CO</smiles>

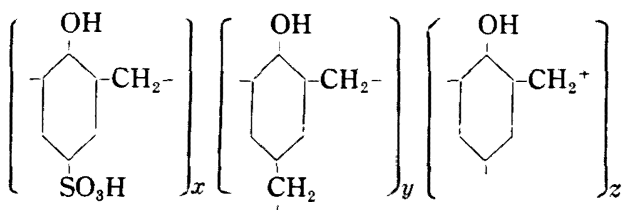

（ただし $x, y, z$ はそれぞれ正の整数）

すなわち(3)式におけるメチロールカチオン（4)式お よび(5)式におけるメチレンカチ十ンがそれである。い らまでもなく，これらのカチオンは樹脂生成反応にあず かるカチオンであって，それぞれのカチオンを単独に選 び出してスルホン酸基上反応させるわけにはいかない。 そのため，モデル物質によってこれらの反応を観察する こととした。

\section{1 メチロールカチオンとスルホン酸基との反応}

メチロールカチオンの生成体としては酸性ホルマリン 液を用い，スルホン酸基童有する化合物としてはPS 樹 脂を用いた。フェノールスルホン酸はホルムアルデヒド と反応寸る際にメチレンカチオンを同時に生成寸るので 用いることができない。

掲題の反応を行なうには所定量の塩酸とホルムアルデ ヒドとを含む水溶液 $500 \mathrm{cc}$ をフラコに入れ, 還流椧 却器をつけて所定温度に加熱し，これに樹脂 $3.00 \mathrm{~g}$ を 投入して反応を開始させ，経時的に一定液量を採取して 遊離した硫酸を EDTA 試薬で定量した。使用した樹

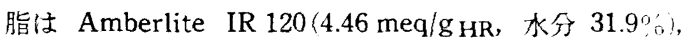

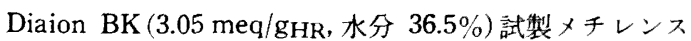
ルホン酸型樹脂 $\left(2.46 \mathrm{meq} / \mathrm{g}_{\mathrm{HR}}\right)$ および試製スルホン化 フェノールホルムアルデヒド樹脂 $(3.49 \mathrm{meq} / \mathrm{g} \mathrm{HR}$, 水分 $57.3 \%$ )である。

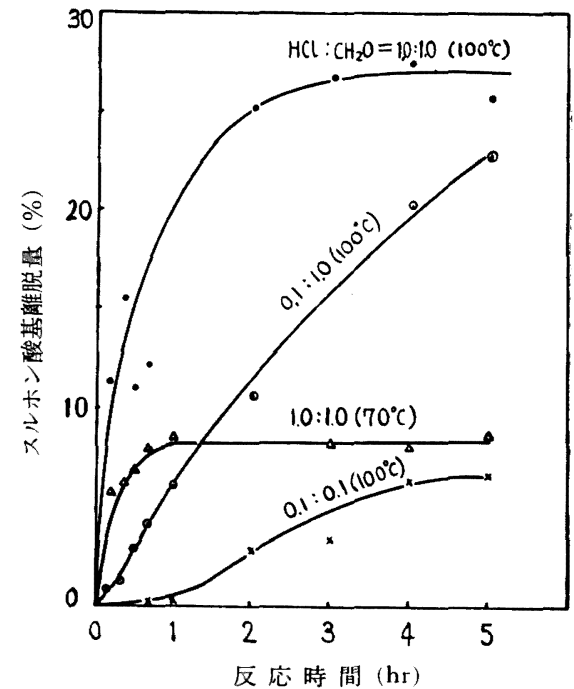

第2図スルホン化フェノールホルムアルデヒド樹 脂に対する酸性ホルマリン液の作用

(図中の数字は Normality を示す)

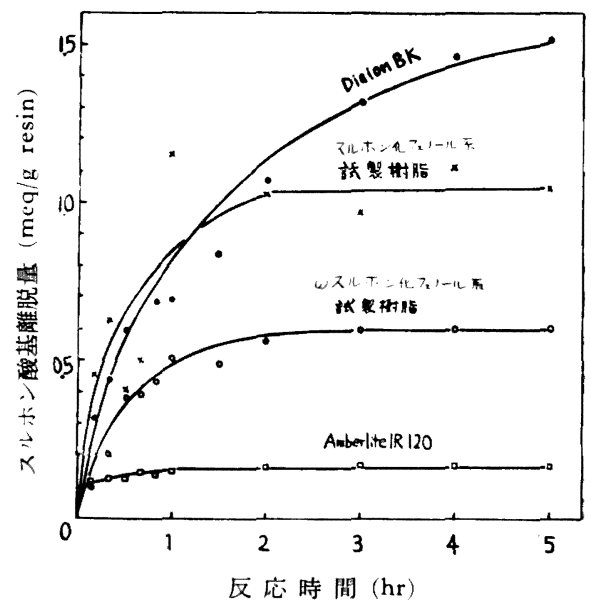

第 3 図各種のスルホン酸型樹脂に対する酸性ホル マリン液の作用

$\left(1 N-\mathrm{HCl}, 1 N-\mathrm{CH}_{2} \mathrm{O}, 100^{\circ} \mathrm{C}\right)$

第 2 図は试製 $\mathrm{PS}$ 樹脂を使用して $\mathrm{HCl} / \mathrm{CH}_{2} \mathrm{O}$ の濃度 比を種々に変化させた場合，ならびに温度を変化させた 場合の結果であって，塩酸およびホルムアルデヒドの多 いほど，また温度の高いほどスルホン酸基の陮脱量は多 くなっている。

第3 図はいろいろなカチオン交換樹脂のスルホン酸基 とメチロールカチオンとの反応性を比較したもので, 次 ページに示すように I, II, III の順序でスルホン酸基離脱 量が大きくなることを示している。 


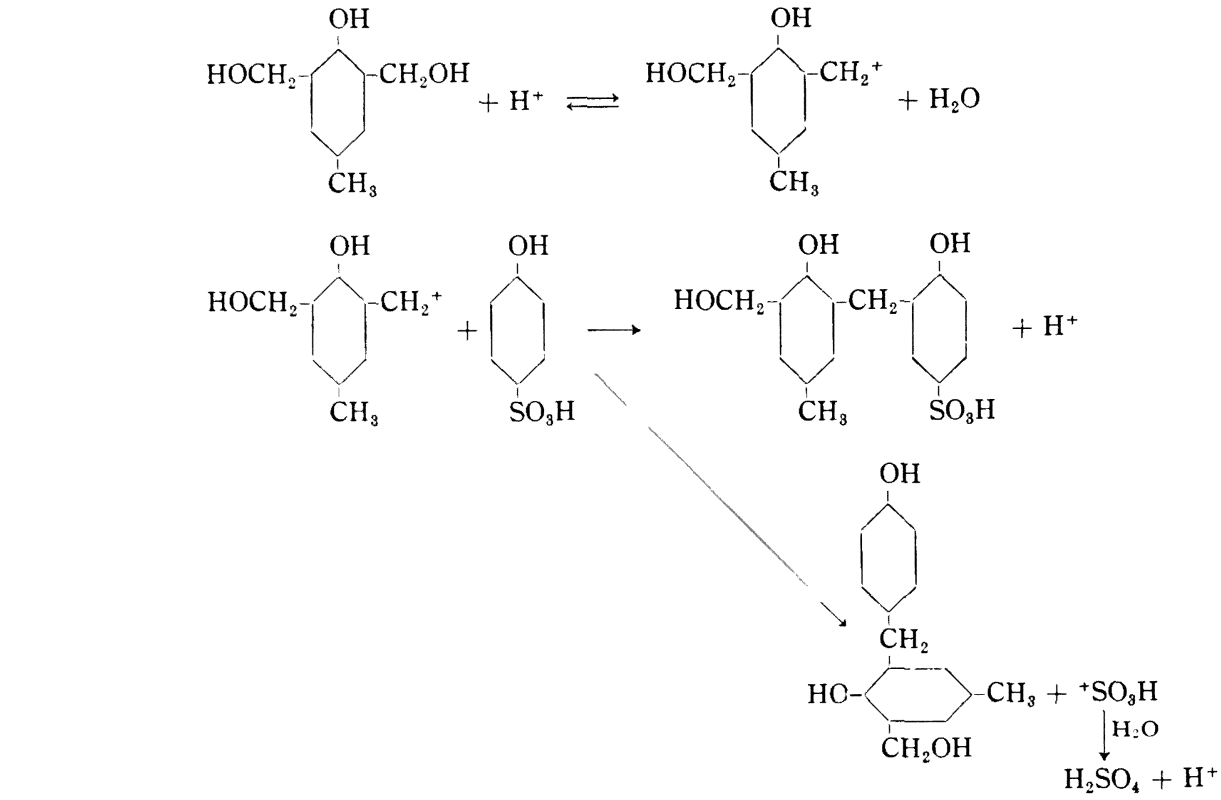<smiles>[CH2]C(C)C1CCCCC1</smiles>
$\mathrm{SO}_{8} \mathrm{H}$

(I)<smiles>[CH2-]C1CCC(CS(=O)(=O)O)CC1O</smiles>

(II)<smiles>[CH]C1CC2CCC(C2)C1O</smiles>

(III)
すでに述へたように，脱スルホン酸基反応をカチナ， イト゚置換反応と考えれば C-S 結合の炭素原子の電荷密 度の大きいはとその反応は起りやすくなるはずであっ て，実験事実はこれ亩裏ゔけるのである。

なおスチロールスルホン酸型樹脂のスルホン酸基はき わめて安定であると考えられているが，メチロールカ千 オンによって㢈脱することは興味ある事実といわなけれ ばならない。

3.2 メレンカチオンとスルホン酸基との反応

メチレンカチォンの生成源として 2,6-ジ×チロール, p-クレソーール (DMPC と略記) の酸性溶液を用いてモデ

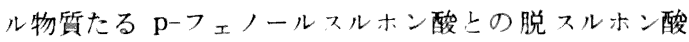
基反応を調ぺた。

DMPC 酸のプロトンと反応してメチレンカチオン を生じ，第 6 式で示すような平衡関係にあるはずである から、このカチオンがもし第 8 式に示すようなカチオ， イド置換反店をすれば，当然硫酸を生成するはずである から、この硫酸根を測定すればメチレンカチオンによる 脱スルホン基反忘が証明されるわけである。

なお，前記のメチレンカチオンは一方ではフェノール スルホン酸と第 7 式のように反応してノボラック型樹脂
を生成すると思われるか゚, 前記の脱スルホン酸基反忘を 定性的に確かめる妨げ上はならないはずである。

実験にあたり，DMPC は Ullmann ${ }^{5)} の$ 方法によって 合成し, p-フェノールスルホン酸ソーダは Obermiller

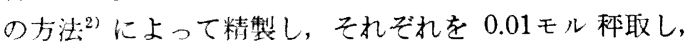
$500 \mathrm{cc}$ の水に溶解してから所定量の塩酸を加えて反応を 開始して経時的に硫酸根を EDTA 試薬で定量した。

第 4 図には温度の影響を、第 5 図には酸濃度の影響を 示した。

これらの実験結果から明らかなように, メチレンカチ オンによる脱スルホン酸基反応は反応温度の高、ほど, また酸濃度の大きいほど著しい。

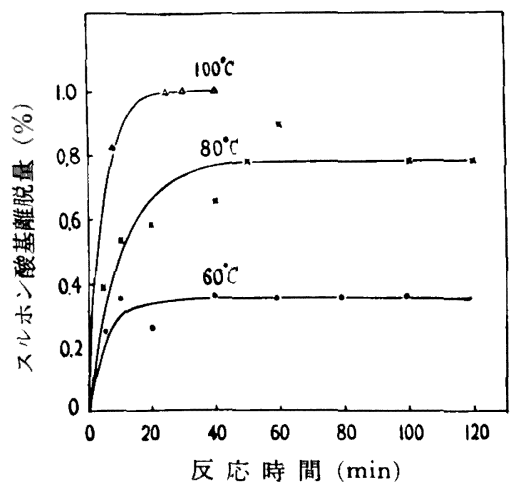

第4図 $\mathrm{p}$-フェノールスルホン酸と2,6-ジメチロー ル $\mathrm{p}$-クレゾールとの反心(温度の影響) 


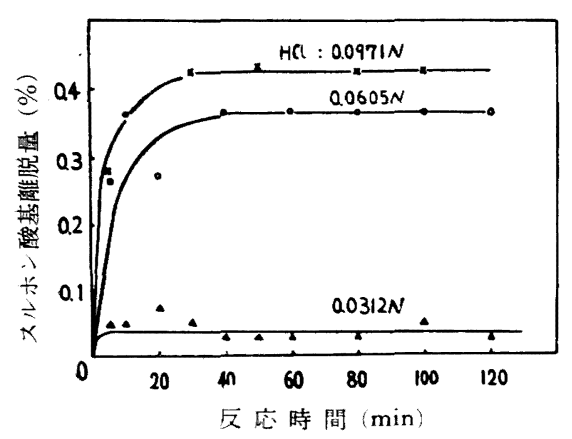

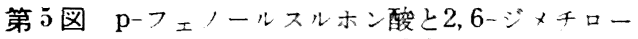
ル $\mathrm{p}-$ タレゾールとの反応 (酸濃度の影響)

\section{3. 結論}

フェノールスルホン酸とホルムアルデヒドとを酸性触 媒の存在で重縮合させる場合のマルホン酸基の䧺脱原因 としてはヒドロニウムイナンによるスルホン酸基のカチ オノイド置換反応よりさ, メチロールカチホン,メチレン カチオンなどのような各種力ルボニウムカ千ナンによる カチオノイド置換反灾の笴与が大きく、美たこのような カルボニウムカチナンの中デ，特にエントロビー因子の 大きいメチロールカチオン，および低分子メチレンカチ オンがスルホン酸基離脱に重要な役割在演ずることが明 らかと夜った。しはがってスルホン酸基の離脱圭さけ一 樹脂化するためには特に反応の初期にホルムアルデヒド および酸の濃度を小さくするような条件が望ましいと考 えられるけれども，之れに伴って重縮合反応が非常に遅
くなるといら難点がある。

そこで著者は希釈系で初期反応老開始したのち共沸の 原理を応用することによって水を留去して反応系を濃縮 することを企て，すでに報告6)したように，この方法を 共沸憁濁重縮合法と名付けた。この方法によればスルホ ン酸基の離脱を防止しつつ初期反応を進めることがで き, しかも，反忘产は低温で能率良く濃縮されて重縮合 反応か促進されるばかりでなく，過剩のホルムアルデヒ ドも同時に留去されるので, 硬化反応過程における脱ス ルホン酸基反応もまた防止することができ，之の上小球 状の樹脂を取得することができるこいう好ましい結果を 得た。

付 記：この研究は, かつ下保士々行化学工業株式会社 研究所において行市ったものであって，その当時絶えず激励ご 援助䘮与的礼た社長吉田一郎氏，元研究所長 比奈地忠平氏 (現在鋼管化学 $\mathrm{KK}$ )，元無機部長清原接三氏 元本社调查室長 高木外次博士 (現在山形大学教授)ならびに本研究に助力された 横山弥八，西村正栄，の雨氏に対し一后く拉礼申上げる。

$$
\text { 文献 }
$$

1) Suter, C.M.: (a) "Organic Reactions", 3, 141, (b) "The Chemistry of Sulfur" (John Wiley \& Sons, Inc.) $387(1948$ )

2) Obermiller, J. : J. Prakt. Chcm., [2], 81, 459 (1911)

3) Hoffmann, K.A. and Biesalski, E.: Ber., 45, 1394 (1912)

4) Munger, J.R. et al : Anal. Chem., 22, 1455 (1950)

5) Ullmann and Britter:Ber., 42, 2539(1909)

6) 芦田：高化, 11, $164(1954)$; 高分子, s, 334 (1959)

\section{Studies on the Ion Exchangers}

\section{The Desulfonation of Sulfonated Phenol Formaldehyde Resin in Acid Catalysed Polycondensation}

\section{By Kaneyoshi Ashida*}

The causes of desulfonation in the course of sulfonated phenol-formaldehyde resin formation are investigated. Model experiments were examined by use of $\mathrm{o}$ - or $\mathrm{p}$ - phenol sulfonic acid, sulfonated phenol formaldehyde resin etc. with hydrochloric acid, acidic solution of formaldehyde or acidic solution of 2,6-dimethylol p- cresol respectively. Consequently it was found that the desulfonation reaction took place by both (a) acid-catalysed hydrolysis and (b) cationoid substitution reaction by methylol cation $\left({ }^{+} \mathrm{CH}_{2} \mathrm{OH}\right)$ or different kinds of methylene cation $\left(\mathrm{RCH}_{2}{ }^{+}\right)$, and the latter reaction (b) is the main cause of the said desulfonation.

* Nisshin Boseki Co. Ltd., Scientific Research Laboratories (1090, Kuriharacho, Adachi-ku, Tokyo) 